\title{
Process performance and modelling of anaerobic digestion using source-sorted organic household waste
}

\author{
Khoshnevisan, Benyamin; Tsapekos, Panagiotis; Alvarado-Morales, Merlin; Angelidaki, Irini
}

Published in:

Bioresource Technology

Link to article, DOI:

10.1016/j.biortech.2017.09.122

Publication date:

2018

Document Version

Peer reviewed version

Link back to DTU Orbit

Citation (APA):

Khoshnevisan, B., Tsapekos, P., Alvarado-Morales, M., \& Angelidaki, I. (2018). Process performance and modelling of anaerobic digestion using source-sorted organic household waste. Bioresource Technology, 247, 486-495. https://doi.org/10.1016/j.biortech.2017.09.122

\section{General rights}

Copyright and moral rights for the publications made accessible in the public portal are retained by the authors and/or other copyright owners and it is a condition of accessing publications that users recognise and abide by the legal requirements associated with these rights.

- Users may download and print one copy of any publication from the public portal for the purpose of private study or research.

- You may not further distribute the material or use it for any profit-making activity or commercial gain

- You may freely distribute the URL identifying the publication in the public portal 


\section{Accepted Manuscript}

Process performance and modelling of anaerobic digestion using source-sorted organic household waste

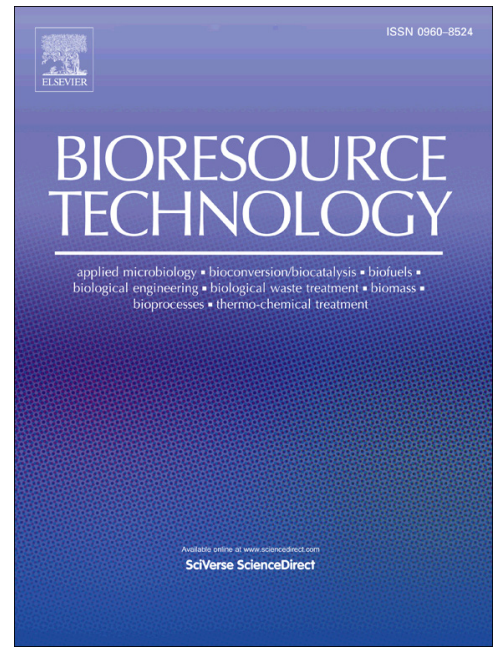

Benyamin Khoshnevisan, Panagiotis Tsapekos, Merlin Alvarado-Morales, Irini Angelidaki

PII:

S0960-8524(17)31687-5

DOI: http://dx.doi.org/10.1016/j.biortech.2017.09.122

Reference: BITE 18950

To appear in:

Bioresource Technology

Received Date:

4 July 2017

Revised Date:

15 September 2017

Accepted Date:

17 September 2017

Please cite this article as: Khoshnevisan, B., Tsapekos, P., Alvarado-Morales, M., Angelidaki, I., Process performance and modelling of anaerobic digestion using source-sorted organic household waste, Bioresource Technology (2017), doi: http://dx.doi.org/10.1016/j.biortech.2017.09.122

This is a PDF file of an unedited manuscript that has been accepted for publication. As a service to our customers we are providing this early version of the manuscript. The manuscript will undergo copyediting, typesetting, and review of the resulting proof before it is published in its final form. Please note that during the production process errors may be discovered which could affect the content, and all legal disclaimers that apply to the journal pertain. 


\section{Process performance and modelling of anaerobic}

\section{digestion using source-sorted organic household waste}

Benyamin Khoshnevisan ${ }^{1,2}$, Panagiotis Tsapekos ${ }^{2}$, Merlin Alvarado-

Morales $^{2}$, Irini Angelidaki ${ }^{2, *}$

${ }^{1}$ Department of Mechanical Engineering of Agricultural machinery, Faculty of Agricultural Engineering and Technology, College of Agriculture and Natural Resources, University of Tehran, Karaj, Iran

${ }^{2}$ Department of Environmental Engineering, Technical University of Denmark, DK-2800, Kgs Lyngby, Denmark

*Corresponding author: Irini Angelidaki, Department of Environmental Engineering, Technical University of Denmark, Bygningstorvet Bygning 115, 2800 Lyngby, Denmark, Phone: (+45) 45251429; Fax: (+45) 45932850; e-mail: iria@env.dtu.dk 


\section{Abstract}

Three distinctive start-up strategies of biogas reactors fed with source-sorted organic fraction of municipal solid waste were investigated to reveal the most reliable procedure for rapid process stabilization. Moreover, the experimental results were compared with mathematical modeling outputs. The initial inoculations to start-up the reactors were 10,50 and $100 \%$ of the final working volume. While a constant feeding rate of $7.8 \mathrm{gVS} / \mathrm{d}$ was considered for the control reactor, the organic loading rate for fed-batch reactors with 10 and $50 \%$ inoculation was progressively increased during a period of 60 and 13 days, respectively. The results clearly demonstrated that an exponentially feeding strategy, considering $50 \%$ inoculation relative to final volume, can significantly decrease the alternatively prolonged period to reach steady conditions, as observed by high biogas and methane production rates. The combination of both experimental and modelling/simulation succeeded in optimizing the start-up process for anaerobic digestion of biopulp under mesophilic conditions.

Keywords: Source-sorted organic household waste; Anaerobic digestion; Start-up period; Biogas; Mathematical modeling 


\section{Introduction}

The surge in world population growth along with the dramatic rise in per capita consumption, caused by industrialization, increased living standards, and globalization, can be identified as the most important factors driving the increase in worldwide energy demand (Khoshnevisan et al., 2015; Rajaeifar et al., 2014). On the other hand, the raised public awareness of this increased energy demand and diminishing fossil resources, as well as the negative environmental pollutions resulted from the huge consumption of fossil origin fuels have pushed researchers to focus on renewable energy sources (Rajaeifar et al., 2014). Organic Fraction of Municipal Solid Waste (OFMSW) is among distinctive renewable sources showing a promising potential to recover energy through anaerobic digestion (AD) (Angelidaki et al., 2006b; Cabbai et al., 2013; Güelfo et al., 2010). Treating OFMSW through $\mathrm{AD}$ has drawn attention due to the low level of sludge generation, lower energy consumption, increased level of methane $\left(\mathrm{CH}_{4}\right)$ production, and the production of a nutrient rich fertilizer (Güelfo et al., 2010; Sonesson et al., 2000). Additionally, AD is a more environmentally friendly method compared with other waste management scenarios because it decreases greenhouse gas emissions (Tian et al., 2017).

Although benefiting from AD, biological treatment of OFMSW suffers from some drawbacks including the slow rate of the process and prone to inhibition due to imbalance between the volatile fatty acids (VFAs) and other precursor-producing bacteria and methanogenic archaea (Ahring et al., 1995; Goberna et al., 2015). The issue discussed is also more problematic when it comes to start-up stage because several parameters including type of inoculum, organic loading rate (OLR), $\mathrm{pH}$, temperature, and hydraulic retention time (HRT) can deeply affect the stability of the process and consequentially, the biomethanation process as well as the kinetics of the first step of $\mathrm{AD}$ (i.e. hydrolysis). For instance, although 
in the literature an OLR between 2 and $6 \mathrm{gVS} / \mathrm{L} / \mathrm{d}$ is typically found (Schnürer et al., 2017), setting-up the optimal initial OLR depends on various parameters as inoculum origin, the time between the collection of inoculum and the start-up of the process, and the temperature of the inoculum (Li et al., 2013; Mao et al., 2015). Setting-up the optimal initial OLR is also important especially during start-up periods because an increase in OLR is typically followed by a decrease in HRT, leading to improper degradation of a specific material under specific operating parameters (Schnürer et al., 2017).

The start-up stage of $\mathrm{AD}$ has gained considerable attention as the proper strategy to initiate the biological treatment of organic compounds can affect the stability of the overall process and consequently, the economic aspects (Garcia-Solano et al., 2016; Janke et al., 2016; Moset et al., 2014). An efficient start-up process would result in adopted microbial communities with higher level of tolerance to inhibition conditions. As reported by Palatsi et al. (2009) a well-established strategy based on feeding patterns can prevent the diverse effects caused by changes in operational conditions and enhance digester performance. Suwannoppadol et al. (2011) conducted a research on start-up of thermophilic anaerobic digestion with the turf fraction of MSW as inoculum. The researchers concluded that during the start-up period, the provision of high buffer capacity and slow stirring are crucial parameters for increased process efficiency.

The evaluation of start-up strategies can be performed using three types of reactor configurations. First, the batch experiments have been periodically employed to assess the highest cumulative biogas and methane yields of specific substrates and/or co-digestion process (Pavi et al., 2017). When a sufficient supply of carbon and nutrient is available, the batch configuration is suitable but "once feeding", i.e., feeding the reactors once starting-up, is considered as a constraint for this type of reactor (Tian et al., 2017). Unless removed via 
biological mediated processes, all substrates, microorganisms, enzymes and products are accumulated in the reactors. Accumulation of inhibitory intermediates in homeostatic threshold concentrations can result in inhibited metabolic reactions within the reactors. Alternatively, fed-batch systems can replace batch reactors and benefit from continuous-flow feeding without fermentation broth removal, and most importantly the concentration of all compounds is kept at low level all the time compared to batch (Ding \& Tan, 2006). However, some other challenges including difficulties in calculating growth rate and sterility issues can arise (Wechselberger et al., 2013). Continuous stirred tank reactors (CSTRs) appear as the third alternative offering a more stable condition while avoiding toxicant accumulation (Tian et al., 2017).

Overall, for a successful start-up, parameters such as inoculum origin and composition as well as feeding strategy should be carefully designed to avoid accumulation of intermediate products such as VFAs and hydrogen which can inhibit the methanogenesis step (Angelidaki et al., 2006b). Thus, it is of major importance to address the challenges aforementioned in order to guarantee an optimal and stable process operation. One way to investigate start-up procedures is with the aid of reliable mathematical models so that experimental effort, cost and risk are minimized. Mathematical models can provide insights into understanding and analyzing important aspects such as inhibition pathways, changes in microbial population dynamics and synergistic effects (Angelidaki et al., 1999). Hence, optimized policies for both start-up and its following operation of $\mathrm{AD}$ reactors can be revealed leading to improved process sustainability.

Although many researches are focusing on either the experimental part of start-up processes or modelling of $\mathrm{AD}$ reactors, only limited attention has been paid to the combination of both experimental and modelling/simulation aspects treating processed 
OFMSW (denoted as "biopulp"). Batch, fed-batch and CSTRs were set up to define the methane potential and optimal start up process for biopulp under mesophilic conditions. Regarding the mathematical model and process simulation, the bioconversion model developed by Angelidaki et al. (1999) and Kovalovszki et al. (2017) was used as starting point to investigate the start-up strategies treating biopulp. Then, model results were validated through the corresponding lab-scale experiments.

\section{Materials and methods}

\subsection{Characterization of inoculum and substrate}

The inoculum used in the current study was supplied from Hashøj full-scale biogas plant (Sealand, Denmark), co-digesting livestock slurries and food industrial wastes under mesophilic conditions. The characteristics of the inoculum are presented in Table 1.

The substrate used was source-sorted organic fraction of municipal solid waste (SSOFMSW) undergone biopulping process for increased biodegradability by Gemidan Ecogi A/S. The total solid (TS) and volatile solid (VS) of concentrated substrate were $128.05 \pm 0.74$ gTS $/ \mathrm{kg}$ and $108.49 \pm 0.45 \mathrm{gVS} / \mathrm{kg}$, respectively. The substrate was diluted with tap water to prevent clogging and stored in plastic bottles at $-20^{\circ} \mathrm{C}$ until feeding to the reactors took place. Table 1 summarizes the characteristics of diluted substrate employed.

\subsection{Batch experiments}

Biochemical Methane Potential (BMP) assay was performed to determine the anaerobic biodegradability of substrate. Batch assays with different organic loads (OL) were performed to find out whether or not the increased OL based on VS content would lead to process inhibition. These series of batch experiments were performed using $1100 \mathrm{~mL}$ glass serum 
bottles. In each assay, a fixed amount of inoculum (i.e., $271 \mathrm{~mL}$ ) was blended with a mixture of substrate and tap water. The volume of added water was $68 \mathrm{~mL}$ and three OLs were examined, i.e., 1, 3 and $5 \mathrm{gVS} / \mathrm{L}$. Accordingly, 6.51, 19.52, and $32.53 \mathrm{~g}$ substrate was added into the bottles and each assay was performed in triplicate. It is worth mentioning that the Inoculum to Substrate Ratio (ISR) was also considered when OLs were chosen. For easily degradable substrates an ISR greater than or equal to four is suggested while for less degradable substrates an ISR less than or equal to one is recommended (Holliger et al., 2016). The main reason for such ISRs proposed is that for easily degradable material rapid accumulation of intermediate products such as VFAs could result in process inhibition. Accordingly, the ISR for OL of $1 \mathrm{gVS} / \mathrm{L}$ and $5 \mathrm{gVS} / \mathrm{L}$ was estimated at 20 and 4, respectively, showing that adopted ISRs were in the range proposed. These ISRs ensured that sufficient active inoculum had been provided as (Holliger et al., 2016).

Anaerobic conditions were established in each bottle during the BMP by flushing the glass serum bottles with nitrogen gas for 5 minutes and sealed immediately with butyl rubber stoppers and aluminum crimps. The sealed bottles were incubated at $37^{\circ} \mathrm{C}$. The incubated bottles were manually shaken once a day during the whole period. The results were compared with blank assays containing only water and inoculum. The subtraction of methane produced by the blank assay and the tested serum bottles showed the methane production potential of fresh substrate. Furthermore, the same assays containing a model substrate were prepared and incubated as control assays for the BMP test. A cellulose standard is suggested to use for municipal biowaste (Angelidaki et al., 2006b), therefore, Avicel was employed as a model substrate to perform control assays. The BMP assays were terminated when no significant gas production was observed in two consecutive measurements. 


\subsection{Kinetics of the BMP assays}

A simplified first-order kinetics focusing on hydrolysis of the process was considered to estimate the cumulative methane production as follows (Tsapekos et al., 2017a):

$$
G(t)=G_{0} \times\left(1-e^{(-k t)}\right)
$$

where $G(t)$ represents the cumulative methane yield at time $t\left(\mathrm{NLCH}_{4} / \mathrm{gVS}\right) ; G_{0}$ stands for the maximum methane potential of the substrate recorded from the BMP assay $\left(\mathrm{NLCH}_{4} / \mathrm{gVS}\right)$; $k$ denotes the methane production rate constant (first order disintegration rate constant) $(1 / \mathrm{d}) ; t$ stands for time (d) of the BMP assay.

\subsection{Start-up procedure of fed-batch and CSTR}

Three reactors were separately run at $37^{\circ} \mathrm{C}$. From now on, these reactors are referred to as $\mathrm{RA}, \mathrm{RB}$, and $\mathrm{RC}$. The total volume of reactors was $4.5 \mathrm{~L}$ while the maximum working volume was determined to be $3.0 \mathrm{~L}$. The required temperature was supplied through recirculating heating water inside the reactor water jackets. Operating on a fed-batch basis, RA and RB were initially started up with 10 and $50 \%$ of the final working volume equal to 0.3 and $1.5 \mathrm{~L}$. In Contrast, RC was filled with $3.0 \mathrm{~L}$ of inoculum equal to $100 \%$ inoculation relative to final volume prior to substrate addition. The content of three reactors was mixed at $30 \mathrm{~s} / \mathrm{min}$ using mechanical stirrers.

Different feeding strategies were employed during the start-up period. RC was fed at a constant feeding rate of $150 \mathrm{~mL} / \mathrm{d}$ corresponding to $7.8 \mathrm{gVS} / \mathrm{d}$, twice a day using a peristaltic pump. Accordingly, the hydraulic retention time (HRT) was 20 days. Regarding the organic loading of the fed-batch reactors, the concept of exponentially active inoculation was followed (Tian et al., 2017). Specifically, for RB, an exponential feeding strategy was followed considering that the working volume of the reactor is converted at a specific rate to 
activated microbiome $(\sim 6 \%)$. The feeding was conducted daily and manually for a period of 13 days to reach $100 \%$ of working volume (as depicted in Fig. S1, supplementary material). Subsequently, a peristaltic pump was used twice a day to operate RB under the same conditions as for RC. For RA, the initial chosen feeding strategy was calculated with the same feeding rate as $\mathrm{RB}$, but the start-up procedure showed failure. Therefore, a more conservative strategy was followed considering a lower feeding rate $(\sim 4 \%)$. The modified logarithmic strategy was conducted for 60 days. Under continuous mode operation, the organic loading rate (OLR) was the same for RA-RC, equal to $2.6 \mathrm{gVS} / \mathrm{L} / \mathrm{d}$.

Shortening the demanded time period is not the only objective of a start-up strategy. The stability of reactor's parameters during and thereafter the start-up period is of important issues. A successful start-up process should finally establish a stable condition in which microbial communities are well-adapted to tolerate stress conditions. Moreover, providing an immense amount of inoculum to start-up a large scale biogas plant is not always possible. Therefore, it is worthy finding out how a successful start-up strategy can be achieved when the start-up of the biogas plants is constrained by the lack of acclimatized and available microbiome. Accordingly, the CSTR reactor was chosen as a control for two adapted feeding strategies.

\subsection{Analytical methods}

Regarding the BMP assays, the methane concentration was measured each twice a week using the gas chromatograph GC-TRACE 1310 equipped with a FID. At every measurement, a specific amount of gas $(0.2 \mathrm{~mL})$ from the head space was extracted and injected to the GC. Concerning the start-up of RA-RC, samples were collected from the reactors every three days. pH was measured with Metrohm $744 \mathrm{pH}$ meter immediately after sampling. Then, samples 
were prepared for VFA analysis. VFA concentrations were measured using GC-TRACE 1300 equipped with a Flame Ionization Detector (FID). A specific amount of sample $(1 \mu \mathrm{L})$ was automatically injected by the Thermo AI/AS 1310 Series Autosampler. Chromatographic separation was achieved on Agilent J\&W GC capillary Column (Length 30 meters, Diam. $0.530 \mathrm{~mm}$, Film thickness $1.50 \mu \mathrm{m}$, Temp limits from $40^{\circ} \mathrm{C}$ to $250^{\circ} \mathrm{C}$ ). The initial column temperature was set to $40^{\circ} \mathrm{C}$ for $6 \mathrm{~min}$, and then it was raised by $20^{\circ} \mathrm{C} / \mathrm{min}$ to $200^{\circ} \mathrm{C}$. The final temperature was held for $6 \mathrm{~min}$ and the total run-time was $20 \mathrm{~min}$, with Helium as carrier gas. The daily biogas production was quantified using the liquid displacement system and the biogas composition was measured every three days. In this context, samples to determine the biogas composition were taken through glass septa twice per week and gas chromatography (Mikrolab, Aarhus A/S, Denmark) was employed to measure methane concentration (Tsapekos et al., 2017b). Following the APHA standard methods (APHA., 1998), the total solids (TS), volatile solids (VS),, chemical oxygen demand (COD) and total ammonia nitrogen (ammonium nitrogen plus free ammonia nitrogen) as well as free ammonia nitrogen were determined. The content of trace elements in the biopulp was quantified using inductively coupled plasma with optical emission spectrometry (ICP-OES).

\subsection{Simulation approach}

The extended dynamic bioconversion model proposed by Kovalovszki et al. (2017) was used to perform the simulations of the start-up strategies in the current study. This model was initially developed by Angelidaki et al. (1999) and is used for modelling and simulation of more complex co-digestion scenarios. A more detailed description of the model can be found in the references aforementioned. The start-up strategy for RA was simulated considering a fed-batch operation starting with a volume of inoculum corresponding to $10 \%$ of the total 
working and increasing the feed flow rate stepwise reaching the total working volume at day 40. Thereafter the reactor operation was shifted to continuous mode, so that the HRT corresponded to 20 days. Similarly, to RA, the start-up for RB was implemented considering an initial volume of inoculum of $50 \%$ of the total working volume and then the feed flow rate was increased stepwise reaching the total working volume at day 10 . Soon after the reactor operation was shifted to continuous mode so that HRT corresponded to 20 days. The start-up strategy for R3 was simulated as continuous mode operation for the entire simulation period considered. Characterization of inoculum and biopulp were used as input for the simulation of the start-up strategies as this a crucial step in obtaining reliable simulation results. The input characterization results are given in Table 1.

\subsection{Data analysis}

Statistics was performed using the OriginPro 9.0.0 SR2 software (OriginLab Corporation, USA). Descriptive statistics were carried out for all variables, mean values and standard deviations were calculated. ANOVA Analysis with a Post Hoc test (Tukey HSD) was conducted to compare and define if significant differences $(p<0.05)$ were observed in experimental measurements.

\section{Results and discussions}

\subsection{BMP results}

The results obtained from BMP assays exhibited that the assays with OL of $5 \mathrm{gVS} / \mathrm{L}$ led to the highest cumulative methane yield, i.e., $0.49 \mathrm{NLCH}_{4} / \mathrm{gVS}$, followed by assays with $\mathrm{OL}$ of $1 \mathrm{gVS} / \mathrm{L}$ (as depicted in Fig. S2, supplementary material). However, the statistical analysis proved that the differences observed among all tests were not significantly meaningful $(\mathrm{p}>$ 
0.05). Angelidaki et al. (2006a) found that the maximum specific methane yield resulted from treating SS-OFMSW under thermophilic conditions was around $0.41 \mathrm{LCH}_{4} / \mathrm{gVS}$. This specific methane yield was achieved at a TS content of $1.5 \%$ and decreased by increasing the TS content. In another study conducted by Hartmann and Ahring (2005) a similar methane yield of $0.40 \mathrm{LCH}_{4} / \mathrm{gVS}$ was reported while treating SS-OFMSW with $30.7 \%$ VS during batch assays at $55^{\circ} \mathrm{C}$. The specific methane yield resulted from BMP assays of fruit and vegetable solid wastes treated under mesophilic conditions ranged from $0.43 \mathrm{LCH}_{4} / \mathrm{gVS}$ to 0.73 $\mathrm{LCH}_{4} / \mathrm{gVS}$ (Gunaseelan, 2004). By comparing the results obtained herein to literature, it is apparent that the obtained methane yields were in the same range found in the literature from similar substrates.

In assays with OL of $1 \mathrm{gVS} / \mathrm{L}$ the achieved methane yield after 4,8 , and 16 days from the starting date was $0.32,0.40$, and $0.42 \mathrm{NLCH}_{4} / \mathrm{gVS}$, respectively. In contrast, the counterparts in assays with $\mathrm{OL}$ of $5 \mathrm{gVS} / \mathrm{L}$ were $0.17,0.23$, and $0.38 \mathrm{NLCH}_{4} / \mathrm{gVS}$, respectively (Figure S.2). This is in line with the fact that the increased OL led to the decreased degradable rate probably due to process overloading where specific microorganisms are inhibited due to accumulation of intermediates. While the degradation of organic matter in assays with OL of $1 \mathrm{gVS} / \mathrm{L}$ was completed within 16 days, this period for assays with OL of $5 \mathrm{gVS} / \mathrm{L}$ was more than 21 days. In better words, in the lowest OL the degradation of biopulp was markedly faster compared to the rest assays; while the difference observed between specific methane yields in three BMPs was no significant. These findings could provide useful information in respect to the selection of appropriate feeding strategies for start-up period.

The maximal theoretical $\mathrm{CH}_{4}$ yield was calculated based on $\mathrm{COD}$ value and compared with the practical $\mathrm{CH}_{4}$ yield. Calculations showed that on average $73 \%$ of the theoretical methane was produced. Owens and Chynoweth (1993) reported a 50\% destruction rate of the 
VS in municipal solid waste. Angelidaki et al. (2006a) and Hartmann and Ahring (2005) demonstrated that $81-84 \%$ of the maximal theoretical yields could be achieved when treating SS-OFMSW. Labatut et al. (2011) illustrated that substrates rich in lipids and easilydegradable carbohydrates yielding the highest methane potential, while more recalcitrant substrates with high lignocellulosic fractions had the lowest. These comparisons well justify that the results obtained herein are in accordance with those reported previously.

The kinetics of the process are also important as they provide information on how rapid the bioconversion process is. Methane production rate constant kinetics of BMP assays with OL of 1,3 and $5 \mathrm{gVS} / \mathrm{L}$ were estimated to be $0.31,0.16$, and 0.07 (1/d), respectively. As observed the methane production rate was decreased as the OL was increased. This can be explained by the fact that the increased organic matter could not be rapidly used by the AD microorganisms in the trails and thus, the rate of biodegradability became lower. Chynoweth et al. (1993) tried to find out the effects of some physicochemical characteristics on biochemical methane potential. Changing the particle size of municipal solid waste from 0.8 $\mathrm{mm}$ to $12.7 \mathrm{~mm}$, they showed that the highest specific first order kinetic constant was observed at the size of $1.6 \mathrm{~mm}$, i.e., $0.21(1 / \mathrm{d})$. In another study conducted by Gunaseelan (2004) first order kinetics was employed to compare the BMPs of fruits and vegetables. They showed that methane production rate constant of fruit wastes ranged from 0.016 to 0.122 $(1 / \mathrm{d})$, and that of vegetable wastes ranged from 0.053 to 0.125 (1/d), respectively. Comparing the results obtained herein with those reported by Chynoweth et al. (1993) proves that the hydrolysis rate of substrate under OL of $1 \mathrm{gVS} / \mathrm{L}$ was markedly quicker than the literature range. It is worthy to be mentioned that the kinetics of the hydrolysis step is predominantly affected by physicochemical characteristics, such as particle size, lignin content, or degree of crystallinity of the lignocellulosic matrix (Labatut et al., 2011). 
Trace elements were also analyzed to investigate whether or not any process failure or degradation rate would be attributed to the presence or absence of a specific element or groups of elements. The knowledge about the amount of trace elements in the substrate is important for two reasons. It has been well-established that these elements are micro-nutrients functioning as microbial agents for the AD of organic materials (Schattauer et al., 2011). For instance, the role of Cobalt and Zinc in methanogenesis is shown to be connected with the expression of methyltransferase and hydrogenases, respectively. Climenhaga and Banks (2008), investigated the effect of micro-nutrients on AD of catering wastes. They reported that reactors with no micro-nutrient supplementation exhibited methanogenic failure while duplicate reactors with micro-nutrient supplementation maintained stable digestion. In contrast, in the present study the non- addition of extra nutrients in the BMP assays was not connected with methanogenic inhibition. The used inoculum was served as a source of all the need micro- and macro-nutrients.

When digestate is used as soil amendment or is used to replace chemical fertilizers, the nutrient value of the digestate is determined by concentration of these micro- and macroelements. A literature review demonstrated that the amount of micro- and macro-nutrients, e.g. manganese, molybdenum, zinc, copper, potassium presented in the substrate lying at the range reported by (Schattauer et al., 2011). Sodium was found in higher concentrations compared to the rest trace elements. The presence of sodium in soil in high concentrations makes plant growth difficult by decreasing plant available water and causing plant stress (Warrence et al., 2002). However, the sodium concentration was not detected to harmful levels so that can provoke problems to soil quality.

\subsection{Start-up procedure of fed-batch and CSTR treating biopulp}


As mentioned in section 2.3, the initial feeding strategy selected for RA was not successful and resulted in imbalanced conditions. Hence, the experimental data of RA were not compared with modeling simulations due to the suboptimal conditions occurred by the initial strategy. Accordingly, the feeding strategy was modified shortly after start-up, i.e., day 15, but until day 40, the productivity including the biogas production and the methane concentration was lower than optimal process performance (Fig. 1). In better words, the adapted start-up strategy from day 0 until day 40 resulted in a suboptimal process performance as observed by low biogas production rate and methane concentrations, as well as accumulation of VFAs. During the start-up period, the VFA accumulation was noticed in parallel with a drop in the $\mathrm{pH}(6.68 \pm 0.67$, average value until day 38$)$. This drop in $\mathrm{pH}$ slowed down the methanogenic activity where the average methane production during this period was $0.13 \mathrm{NL} / \mathrm{L} / \mathrm{d}$ (Fig. 1a). As expected, during the imbalanced conditions, the total ammonia levels did not show a significant increase during this period (Fig. 2c) because the ammonia concentration was higher in inoculum than in the substrate. The average value of total ammonia for the first 38 days was calculated as $2.11 \pm 0.41 \mathrm{gN} / \mathrm{L}$. The new implemented feeding strategy resulted in a positive effect on the reactor performance as observed by an increase in both biogas and methane production rates, as detected after day 35 .

Although the feeding strategy was modified after the first 15 days, a "lag phase" can be distinguished between day 15 and day 40 where the productivity was still low. This "lag phase" can be explained by the accumulation of intermediates during the initial start-up period and continued until the microbial communities could adapt themselves to the environment. This is most likely due to that during the first start-up period the inlet flow rate was higher than the rate of consumption/production within the biological system. Therefore, the 
microorganisms did not have enough time to metabolize the substrates and intermediates as they were piling up.

Contrary, when the feeding strategy was modified the rate of consumption/production within the system became higher than the inlet flow rate. Moreover, the smoother increasing feeding rate gave the microbial community the opportunity to be more adapted and so, the AD system could be recovered from the initial failure. However, an extended amount of time was needed for methanogenic community to efficiently metabolize the accumulated VFA. Indeed, as depicted in Figure 2b, after 50 days from the initial start-up the T-VFA concentration significantly dropped to the value of $0.23 \mathrm{~g} / \mathrm{L}$ and stayed below $1.1 \mathrm{~g} / \mathrm{L}$ thereafter. This drop in VFA accumulation and the associated increased methane yield confirmed the presence of a more balanced and active microbial community as result of the modified feeding strategy. Furthermore, $\mathrm{pH}$ values showed a stable condition and followed the normal values for an optimal operation of $\mathrm{AD}(7.0-8.0)$.

The performance of $\mathrm{RB}$ is depicted in Figures 3 and 4. The selected start-up strategy resulted in an optimal process performance as observed by high biogas and methane production rates. As can be seen, the biogas and methane production were close to the simulation results except in two short periods. The first period occurred between day 30 and 38 where the biogas and methane production showed a slight reduction. During this period, no accumulation of T-VFA and drop in $\mathrm{pH}$ were observed (Fig. 4a and 4b). The drop in biogas production was caused by lower feeding due to failure in the peristaltic pump performance. The second period was observed between day 46 and 55. This drop in biogas and methane production was accompanied by increased acetic acid and T-VFA. This is because during the mentioned period there was a problem with the reactor stirrer. The non-uniform mixing occurred in this period caused the accumulation of mainly acetate (Fig. 3c) resulting in a drop 
in both biogas and methane production rates. The decrease in biogas production was also accompanied by an increase in the intermediate products, i.e., acetic acid, as shown in Fig. 3c. The importance of proper mixing during $\mathrm{AD}$ process has been widely investigated and reported by several researchers (Kaparaju et al., 2008; Karim et al., 2005). It has been wellstablished that appropriate mixing of the substrate in the digester helps to distribute the microbiome uniformly throughout the reactor (Karim et al., 2005). Moreover, the biological conversion can benefit from uniform heat transfer and particle size distribution caused by correct mixing of the substrate in the digester (Kaparaju et al., 2008). More importantly, appropriate mixing helps to avoid the formation of dead zones in reactors (Kaparaju et al., 2008; Karim et al., 2005). However, it should be mentioned that after stirring fixation the microbiome quickly recovered and reactor's performance was in accordance with BioModel's predictions.

As observed in Figure 4c, thirty days from the initial start-up the ammonium concentrations started to show a decreasing trend and thereafter, remaining lower than $1.1 \mathrm{~g}$ N/L. Moreover, the total ammonia nitrogen obtained from experimental results could be completely forecasted by the model simulations during the whole experimental period (Fig. 4c). Comparing the results obtained from experimental data and those from simulations clearly depicted to be successful for AD of biopulp under developed starting-up strategy.

Performance of RC is illustrated in Figure 5 and 6 . As can be observed, ten days after reactor's initiation the biogas and methane production reached to the maximum rate, while the $\mathrm{pH}$ stayed in the acceptable range for methanogenesis. In contrast, a slight accumulation of propionate can be noticed in the start-up period (Fig. 5c). Specifically, during the first 10 days the increase in biogas and methane production was accompanied by a parallel increase in propionate concentration. Thereafter, a drop in biogas production and methane concentration 
was noticed. From day 16, the gas production started increasing while propionate was still in high concentrations. Typically, propionate accumulates during suboptimal conditions (Boe et al., 2010). The observed accumulation could be attributed to the high OLR for the un-adapted microbial communities to the biopulp and more specifically, propionate degraders most probably were not well-developed yet. This is in line with the results reported by Boe et al. (2010), who showed that while acetate and butyrate started to decrease after exposing the reactor to organic overload for some time, in contrast propionate kept accumulating due to the slow growing rate. Nielsen et al. (2007) also suggested propionate concentration as suitable parameter to indicate imbalance in reactors. It is worth mentioning that, in spite of the fact that propionate concentration can be used to interpreter the process stress, it cannot be directly used as a simplified and early warning indicator for monitoring the process failure of $\mathrm{AD}$ system ( $\mathrm{Li}$ et al., 2014). In this context, a combination of parameters as T-VFA, the ratio of VFA to total alkalinity, and the ratio of bicarbonate alkalinity to total alkalinity have been suggested (Li et al., 2014). However, as shown in Figure 5c after some days of continuous mode operation the propionate concentrations dropped to very low values indicating that the reactor performed fine. Furthermore, both $\mathrm{pH}$ and total ammonia nitrogen were perfectly predicted by simulations and showed a stable AD process.

With respect to bioenergy productivity start-up period operation of RB-RC were adequately predicted by BioModel simulations (Fig. 3 and 5). Moreover, the model could successfully match the experimental results for $\mathrm{pH}$ and total ammonium nitrogen (Fig. 4 and 6). In contrast, the inhibition occurred in the early stage development of RA, stressed significantly its microbiome; and thus, did not allow the BioModel to predict successfully the start-up period. However, RA could have similar process efficiency to RB-RC without instabilities in the long run based on BioModel simulations (data not shown). Overall, 
reactor's monitoring in the lab at continuous mode operation showed that both bioenergy output and biochemical parameters were in comparable levels with the results obtained in RBRC. However, for future application a further adjustment of BioModel parameters is needed to efficiently forecast reactors behavior operating under stressed conditions.

The specific methane yield during the start-up period and stable conditions thereafter were precisely monitored. The specific methane yield during the start-up period experienced rather unstable conditions due to aforementioned reasons. The trend obtained proves that the three reactors reached the stable conditions after day 60. The average specific methane yield (normalized value based on at standard temperature and pressure (STP) conditions) for RA, $\mathrm{RB}$, and $\mathrm{RC}$ during the last 10 days, i.e., between day 60 and day 70 , was calculated as 0.49 , 0.45, $0.39 \mathrm{NLCH}_{4} / \mathrm{gVS}$, respectively. Interestingly, the methane yield between the two most efficient CSTRs did not differ significantly $(\mathrm{p}>0.05)$. Furthermore, during this period the average methane content was estimated at 63\%. Pavan et al. (2000) conducted a research to evaluate the performance of thermophilic semi-dry anaerobic digestion process. They reported that at a feeding rate of $9.7 \mathrm{kgVS} / \mathrm{m}^{3} / \mathrm{d}$, a methane yield of $0.32 \mathrm{LCH}_{4} / \mathrm{gVS}$ was achieved. In another study conducted by Angelidaki et al. (2006a) the start-up procedure for CSTR treating SS-OFMSW under thermophilic condition was investigated. Filling the reactor at a progressively increasing rate, they reported that the maximum specific methane yield of 0.32 $\mathrm{NLCH}_{4} / \mathrm{gVS}$ was produced during a 30 day start-up period. This methane yield was achieved while $4.28 \mathrm{gVS} / \mathrm{L}$ was fed to reactor. Table 2 summarizes some results from previous studies on methane yield for organic fraction of municipal solid waste. As can be observed the methane yields reported in the literature are in the range of $0.30-0.60 \mathrm{LCH}_{4} / \mathrm{gVS}$. The difference observed between the results obtained herein and those reported in the literature 
can be attributed to several factors such as HRT, TS content, substrate's chemical composition, microbial community, etc.

Overall, it can be concluded that the strategy including 50\% inoculation with increasing feeding rate, was the most secure (i.e. avoiding the danger of inhibition) and efficient policy (i.e. high bioenergy output). Specifically, this scenario reduced the initial start-up volume to the half, with the least process imbalances in terms of $\mathrm{pH}$ drop, VFAs or $\mathrm{NH}_{4}$ accumulation. Moreover, the strategy of $50 \%$ inoculation resulted in reaching quickly steady conditions. In other words, starting-up with $50 \%$ inoculation followed by a conservative and exponential feeding strategy able to convert at a specific rate the added feedstock into active microbiome gives good possibilities to have quickly the desired process stability compared to $10 \%$ strategy which should be also associated with extended time to avoid toxicity. The findings of the present study are so important especially when the start-up of the biogas plants is constrained by the lack of acclimatized and available inoculum.

\section{Conclusions}

The results of the present study indicated that starting-up with 50\% inoculation following an exponential feeding strategy was the best strategy for treating source-sorted organic fraction of municipal solid waste. The most reliable strategy could reduce the initial volume to start-up the reactor to the half, as such it did not show process imbalances in terms of $\mathrm{pH}$

drop, VFAs or $\mathrm{NH}_{4}-\mathrm{N}$ accumulation. Moreover, the selected procedure did not reveal any lag phase and quickly led to steady state conditions. Simulations with BioModel validated that the selected strategy can lead to relatively high biogas productivity without risk of inhibition.

\section{Acknowledgements}


We acknowledge financial support from MUDP project "VARGA - VAnd Ressource Genvindings Anlægget', We also thank Gemidan Ecogi A/S for biopulp providing and Hector Garcia for the technical assistance.

\section{References:}

1. Ahring, B.K., Sandberg, M., Angelidaki, I. 1995. Volatile fatty acids as indicators of process imbalance in anaerobic digestors. Applied microbiology and biotechnology, 43(3), 559-565.

2. Angelidaki, I., Chen, X., Cui, J., Kaparaju, P., Ellegaard, L. 2006a. Thermophilic anaerobic digestion of source-sorted organic fraction of household municipal solid waste: start-up procedure for continuously stirred tank reactor. Water research, 40(14), 26212628.

3. Angelidaki, I., Cui, J., Chen, X., Kaparaju, P. 2006b. Operational strategies for thermophilic anaerobic digestion of organic fraction of municipal solid waste in continuously stirred tank reactors. Environmental technology, 27(8), 855-861.

4. Angelidaki, I., Ellegaard, L., Ahring, B.K. 1999. A comprehensive model of anaerobic bioconversion of complex substrates to biogas. Biotechnology and bioengineering, 63(3), $363-372$.

5. APHA. 1998. Wpcf. Standard methods for the examination of water and wastewater, 20.

6. Boe, K., Batstone, D.J., Steyer, J.-P., Angelidaki, I. 2010. State indicators for monitoring the anaerobic digestion process. Water research, 44(20), 5973-5980.

7. Bouallagui, H., Haouari, O., Touhami, Y., Cheikh, R.B., Marouani, L., Hamdi, M. 2004. Effect of temperature on the performance of an anaerobic tubular reactor treating fruit and vegetable waste. Process Biochemistry, 39(12), 2143-2148. 
8. Cabbai, V., Ballico, M., Aneggi, E., Goi, D. 2013. BMP tests of source selected OFMSW to evaluate anaerobic codigestion with sewage sludge. Waste management, 33(7), 16261632.

9. Chen, X., Romano, R.T., Zhang, R. 2010. Anaerobic digestion of food wastes for biogas production. International Journal of Agricultural and Biological Engineering, 3(4), 61-72.

10. Chynoweth, D., Turick, C., Owens, J., Jerger, D., Peck, M. 1993. Biochemical methane potential of biomass and waste feedstocks. Biomass and Bioenergy, 5(1), 95-111.

11. Climenhaga, M., Banks, C. 2008. Anaerobic digestion of catering wastes: effect of micronutrients and retention time. Water Science and Technology, 57(5), 687-692.

12. Davidsson, Å., Gruvberger, C., Christensen, T.H., Hansen, T.L., la Cour Jansen, J. 2007. Methane yield in source-sorted organic fraction of municipal solid waste. Waste management, 27(3), 406-414.

13. Ding, S., Tan, T. 2006. L-lactic acid production by Lactobacillus casei fermentation using different fed-batch feeding strategies. Process Biochemistry, 41(6), 1451-1454.

14. Garcia-Solano, M., Méndez-Acosta, H.O., Puebla, H., Hernandez-Martinez, E. 2016. Dynamic characterization of an anaerobic digester during the start-up phase by $\mathrm{pH}$ timeseries analysis. Chaos, Solitons \& Fractals, 82, 125-130.

15. Ghanimeh, S., El Fadel, M., Saikaly, P. 2012. Mixing effect on thermophilic anaerobic digestion of source-sorted organic fraction of municipal solid waste. Bioresource technology, 117, 63-71.

16. Goberna, M., Gadermaier, M., Franke-Whittle, I., García, C., Wett, B., Insam, H. 2015. Start-up strategies in manure-fed biogas reactors: Process parameters and methanogenic communities. Biomass and Bioenergy, 75, 46-56. 
17. Güelfo, L.F.-., Alvarez-Gallego, C., Márquez, D.S., García, L.R. 2010. Start-up of thermophilic-dry anaerobic digestion of OFMSW using adapted modified SEBAC inoculum. Bioresource technology, 101(23), 9031-9039.

18. Gunaseelan, V.N. 2004. Biochemical methane potential of fruits and vegetable solid waste feedstocks. Biomass and Bioenergy, 26(4), 389-399.

19. Hartmann, H., Ahring, B.K. 2005. Anaerobic digestion of the organic fraction of municipal solid waste: influence of co-digestion with manure. Water research, 39(8), $1543-1552$.

20. Holliger, C., Alves, M., Andrade, D., Angelidaki, I., Astals, S., Baier, U., Bougrier, C., Buffière, P., Carballa, M., de Wilde, V. 2016. Towards a standardization of biomethane potential tests. Water Science and Technology, 74(11), 2515-2522.

21. Janke, L., Leite, A.F., Nikolausz, M., Radetski, C.M., Nelles, M., Stinner, W. 2016. Comparison of start-up strategies and process performance during semi-continuous anaerobic digestion of sugarcane filter cake co-digested with bagasse. Waste management, 48, 199-208.

22. Jiang, Y., Heaven, S., Banks, C.J. 2012. Strategies for stable anaerobic digestion of vegetable waste. Renewable energy, 44, 206-214.

23. Kaparaju, P., Buendia, I., Ellegaard, L., Angelidakia, I. 2008. Effects of mixing on methane production during thermophilic anaerobic digestion of manure: lab-scale and pilot-scale studies. Bioresource technology, 99(11), 4919-4928.

24. Karim, K., Hoffmann, R., Klasson, K.T., Al-Dahhan, M. 2005. Anaerobic digestion of animal waste: Effect of mode of mixing. Water research, 39(15), 3597-3606.

25. Khoshnevisan, B., Bolandnazar, E., Barak, S., Shamshirband, S., Maghsoudlou, H., Altameem, T.A., Gani, A. 2015. A clustering model based on an evolutionary algorithm 
for better energy use in crop production. Stochastic environmental research and risk assessment, 29(8), 1921-1935.

26. Kovalovszki, A., Alvarado-Morales, M., Fotidis, I.A., Angelidaki, I. 2017. A systematic methodology to extend the applicability of a bioconversion model for the simulation of various co-digestion scenarios. Bioresource technology, 235, 157-166.

27. Labatut, R.A., Angenent, L.T., Scott, N.R. 2011. Biochemical methane potential and biodegradability of complex organic substrates. Bioresource technology, 102(3), 22552264.

28. Li, C., Champagne, P., Anderson, B. 2013. Biogas production performance of mesophilic and thermophilic anaerobic co-digestion with fat, oil, and grease in semi-continuous flow digesters: effects of temperature, hydraulic retention time, and organic loading rate. Environmental technology, 34(13-14), 2125-2133.

29. Li, L., He, Q., Wei, Y., He, Q., Peng, X. 2014. Early warning indicators for monitoring the process failure of anaerobic digestion system of food waste. Bioresource technology, 171, 491-494.

30. Mao, C., Feng, Y., Wang, X., Ren, G. 2015. Review on research achievements of biogas from anaerobic digestion. Renewable and Sustainable Energy Reviews, 45, 540-555.

31. Moset, V., Bertolini, E., Cerisuelo, A., Cambra, M., Olmos, A., Cambra-López, M. 2014. Start-up strategies for thermophilic anaerobic digestion of pig manure. Energy, 74, 389395.

32. Nielsen, H.B., Uellendahl, H., Ahring, B.K. 2007. Regulation and optimization of the biogas process: propionate as a key parameter. Biomass and Bioenergy, 31(11), 820-830.

33. Owens, J., Chynoweth, D. 1993. Biochemical methane potential of municipal solid waste (MSW) components. Water Science and Technology, 27(2), 1-14. 
34. Palatsi, J., Laureni, M., Andrés, M., Flotats, X., Nielsen, H.B., Angelidaki, I. 2009. Strategies for recovering inhibition caused by long chain fatty acids on anaerobic thermophilic biogas reactors. Bioresource technology, 100(20), 4588-4596.

35. Pavan, P., Battistoni, P., Cecchi, F., Mata-Alvarez, J. 2000. Two-phase anaerobic digestion of source sorted OFMSW (organic fraction of municipal solid waste): performance and kinetic study. Water Science and Technology, 41(3), 111-118.

36. Pavi, S., Kramer, L.E., Gomes, L.P., Miranda, L.A.S. 2017. Biogas production from codigestion of organic fraction of municipal solid waste and fruit and vegetable waste. Bioresource technology.

37. Rajaeifar, M.A., Akram, A., Ghobadian, B., Rafiee, S., Heidari, M.D. 2014. Energyeconomic life cycle assessment (LCA) and greenhouse gas emissions analysis of olive oil production in Iran. Energy, 66, 139-149.

38. Schattauer, A., Abdoun, E., Weiland, P., Plöchl, M., Heiermann, M. 2011. Abundance of trace elements in demonstration biogas plants. Biosystems Engineering, 108(1), 57-65.

39. Schnürer, A., Bohn, I., Moestedt, J. 2017. Protocol for Start-Up and Operation of CSTR Biogas Processes. Hydrocarbon and Lipid Microbiology Protocols: Bioproducts, Biofuels, Biocatalysts and Facilitating Tools, 171-200.

40. Sonesson, U., Björklund, A., Carlsson, M., Dalemo, M. 2000. Environmental and economic analysis of management systems for biodegradable waste. Resources, conservation and recycling, 28(1), 29-53.

41. Suwannoppadol, S., Ho, G., Cord-Ruwisch, R. 2011. Rapid start-up of thermophilic anaerobic digestion with the turf fraction of MSW as inoculum. Bioresource technology, 102(17), 7762-7767. 
42. Tian, H., Fotidis, I.A., Mancini, E., Angelidaki, I. 2017. Different cultivation methods to acclimatise ammonia-tolerant methanogenic consortia. Bioresource technology, 232, 1-9.

43. Tsapekos, P., Kougias, P., Egelund, H., Larsen, U., Pedersen, J., Trénel, P., Angelidaki, I. 2017a. Mechanical pretreatment at harvesting increases the bioenergy output from marginal land grasses. Renewable energy, 111, 914-921.

44. Tsapekos, P., Kougias, P., Treu, L., Campanaro, S., Angelidaki, I. 2017b. Process performance and comparative metagenomic analysis during co-digestion of manure and lignocellulosic biomass for biogas production. Applied Energy, 185, 126-135.

45. Warrence, N.J., Bauder, J.W., Pearson, K.E. 2002. Basics of salinity and sodicity effects on soil physical properties. Departement of Land Resources and Environmental Sciences, Montana State University-Bozeman, MT.

46. Wechselberger, P., Sagmeister, P., Herwig, C. 2013. Real-time estimation of biomass and specific growth rate in physiologically variable recombinant fed-batch processes.

Bioprocess and biosystems engineering, 36(9), 1205-1218. 


\section{Figure captions}

Fig. 1. RA - Reactor performance: a) biogas production rate, b) methane production rate, c) Propionate concentration, d) Acetate concentration. Blue circles - experimental data, blue straight line - simulation results

Fig. 2. RA - Reactor performance: a) pH, b) T-VFA, c) Total ammonia nitrogen. Blue circles - experimental data, blue straight line - simulation results

Fig. 3. RB - Reactor performance: a) biogas production rate, b) methane production rate, c) Propionate concentration, d) Acetate concentration. Green circles - experimental data, green straight line - simulation results.

Fig. 4. RB - Reactor performance: a) pH, b) T-VFA, c) Total ammonia nitrogen. Green circles - experimental data, green straight line - simulation results.

Fig. 5. RC - Reactor performance: a) biogas production rate, b) methane production rate, c) Propionate concentration, d) Acetate concentration. Red circles - experimental data, red straight line - simulation results.

Fig. 6. RC - Reactor performance: a) pH, b) T-VFA, c) Total ammonia. Red circles experimental data, red straight line - simulation results. 


\section{Tables}

Table 1. Characteristics of inoculum and substrate

\begin{tabular}{|c|c|c|c|}
\hline Parameter & Unit & Inoculum (stdev) & Biopulp (stdev) \\
\hline TS & $\mathrm{g} / \mathrm{kg}$ & $38.61(0.34)$ & $60.52(0.52)$ \\
\hline VS & $\mathrm{g} / \mathrm{kg}$ & $24.07(0.35)$ & $52.11(0.55)$ \\
\hline $\mathrm{pH}$ & & 8.38 & 3.90 \\
\hline TAN & $\mathrm{gNH}_{4}-\mathrm{N} / \mathrm{L}$ & $3.80(0.01)$ & $0.40(0.01)$ \\
\hline FAN & $\mathrm{gNH}_{3}-\mathrm{N} / \mathrm{L}$ & $0.82(0.01)$ & - \\
\hline TKN & gTKN/L & $5.38(0.25)$ & $1.70(0.03)$ \\
\hline TFA & $\mathrm{g} / \mathrm{L}$ & $0.16(0.08)$ & $3.92(0.38)$ \\
\hline COD & $\mathrm{g} / \mathrm{L}$ & $\mathrm{nm}$ & $83.95(3.01)$ \\
\hline Total Carbohydrate & $\mathrm{g} / \mathrm{L}$ & $\mathrm{nm}$ & $31.55(1.58)$ \\
\hline Total Protein & $\mathrm{g} / \mathrm{L}$ & $\mathrm{nm}$ & $9.08(0.45)$ \\
\hline Total Lipid & $\mathrm{g} / \mathrm{L}$ & $\mathrm{nm}$ & $7.87(0.39)$ \\
\hline Acetate & $\mathrm{g} / \mathrm{L}$ & $0.14(0.05)$ & $3.10(0.09)$ \\
\hline Propionate & $\mathrm{g} / \mathrm{L}$ & $0.03(0.01)$ & $0.24(0.01)$ \\
\hline Hexanol & $\mathrm{g} / \mathrm{L}$ & $0.00(0.01)$ & $0.11(0.01)$ \\
\hline Ethanol & $\mathrm{g} / \mathrm{L}$ & $0.02(0.01)$ & $3.83(0.20)$ \\
\hline Butyrate & $\mathrm{g} / \mathrm{L}$ & $0.00(0.01)$ & $0.20(0.01)$ \\
\hline Isobutyrate & $\mathrm{g} / \mathrm{L}$ & $0.03(0.01)$ & $0.01(0.01)$ \\
\hline $\mathrm{Al}$ & $\mathrm{g} / \mathrm{kgTS}$ & $\mathrm{nm}$ & $1.15(0.27)$ \\
\hline $\mathrm{Ca}$ & $\mathrm{g} / \mathrm{kgTS}$ & $\mathrm{nm}$ & $20.46(1.73)$ \\
\hline $\mathrm{Cu}$ & $\mathrm{g} / \mathrm{kgTS}$ & $\mathrm{nm}$ & $0.02(0.00)$ \\
\hline $\mathrm{K}$ & $\mathrm{g} / \mathrm{kgTS}$ & $\mathrm{nm}$ & $9.80(0.77)$ \\
\hline $\mathrm{Mg}$ & $\mathrm{g} / \mathrm{kgTS}$ & $\mathrm{nm}$ & $1.96(0.11)$ \\
\hline $\mathrm{Mn}$ & g/kgTS & $\mathrm{nm}$ & $0.15(0.01)$ \\
\hline $\mathrm{Na}$ & $\mathrm{g} / \mathrm{kgTS}$ & $\mathrm{nm}$ & $8.19(0.47)$ \\
\hline $\mathrm{P}$ & $\mathrm{g} / \mathrm{kgTS}$ & $\mathrm{nm}$ & $2.73(0.16)$ \\
\hline S & $\mathrm{g} / \mathrm{kgTS}$ & $\mathrm{nm}$ & $2.66(0.15)$ \\
\hline $\mathrm{Sr}$ & $\mathrm{g} / \mathrm{kgTS}$ & $\mathrm{nm}$ & $0.09(0.01)$ \\
\hline $\mathrm{Fe}$ & $\mathrm{g} / \mathrm{kgTS}$ & $\mathrm{nm}$ & $1.36(0.01)$ \\
\hline $\mathrm{Ba}$ & $\mathrm{g} / \mathrm{kgTS}$ & $\mathrm{nm}$ & $0.04(0.01)$ \\
\hline
\end{tabular}


Table 2. Some results from previous studies on methane yield for OFMSW

\begin{tabular}{|c|c|c|c|c|c|c|}
\hline Ref. & Scale & Waste type & Temperature & $\begin{array}{l}\text { Total/working volume } \\
\text { L }\end{array}$ & $\begin{array}{l}\text { OLR } \\
\text { gVS/L/d }\end{array}$ & $\begin{array}{l}\text { Specific methane yield } \\
\mathrm{LCH}_{4} / \mathrm{gVS}\end{array}$ \\
\hline (Ghanimeh et al., 2012) & Lab S. & SS-OFMSW & Thermophilic & $14 / 9$ & $0.45-2.5$ & 0.33 \\
\hline (Jiang et al., 2012) & Lab S. & Vegetable waste & Mesophilic & $5 / 4$ & 2 & 0.35 \\
\hline (Chen et al., 2010) & Lab S. & Food waste & Mesophilic & $20 / 18$ & 0.5 & 0.32 \\
\hline (Climenhaga \& Banks, 2008) & Lab S. & SS-OFMSW & Mesophilic & $5 /$ na & 1.45 & 0.58 \\
\hline (Bouallagui et al., 2004) & Lab S. & Vegetable waste & Mesophilic & na & 2.8 & 0.42 \\
\hline (Davidsson et al., 2007) & Pilot S. & SS-OFMSW & Thermophilic & 35 & 2.8 & $0.30-0.40$ \\
\hline
\end{tabular}



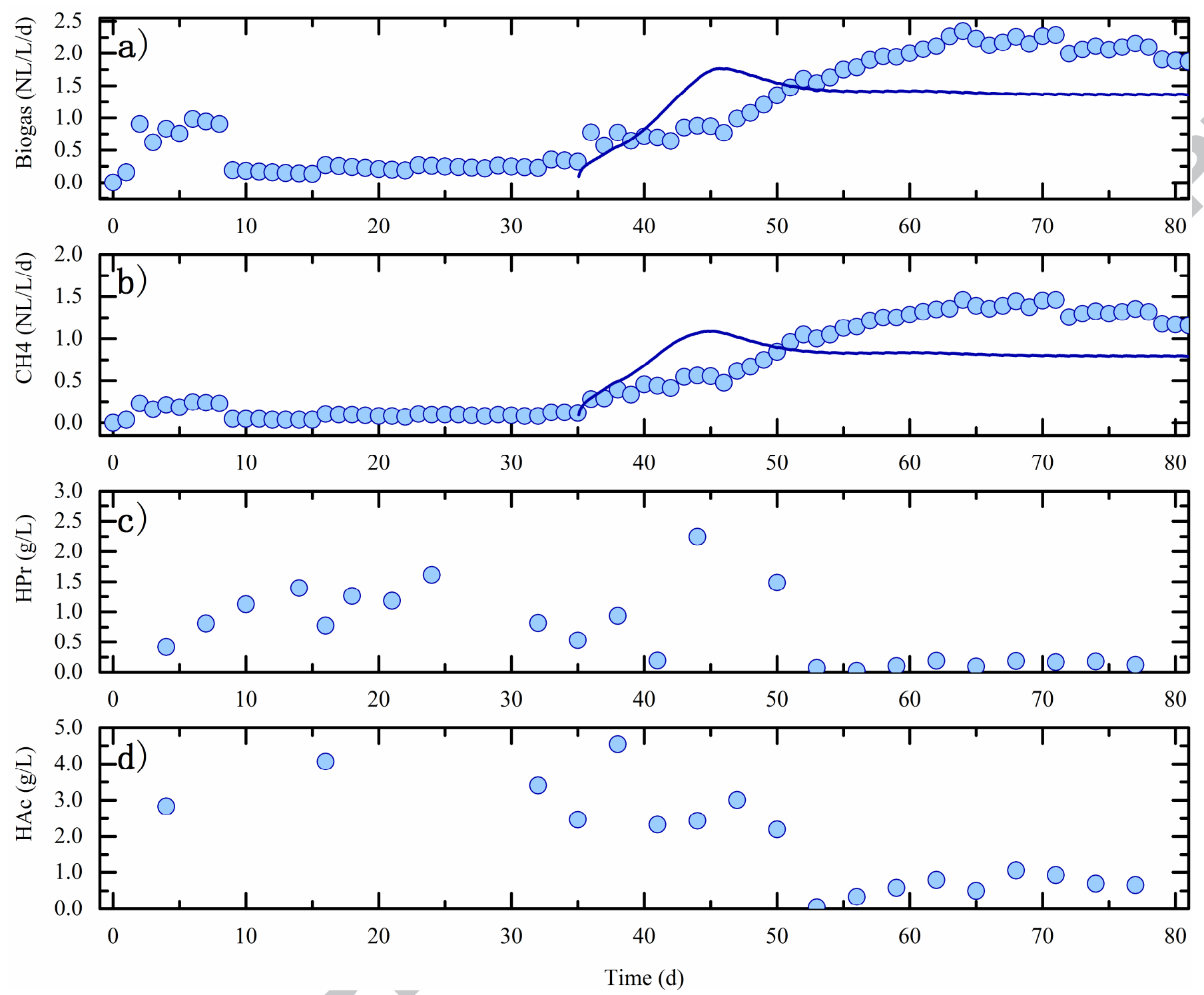

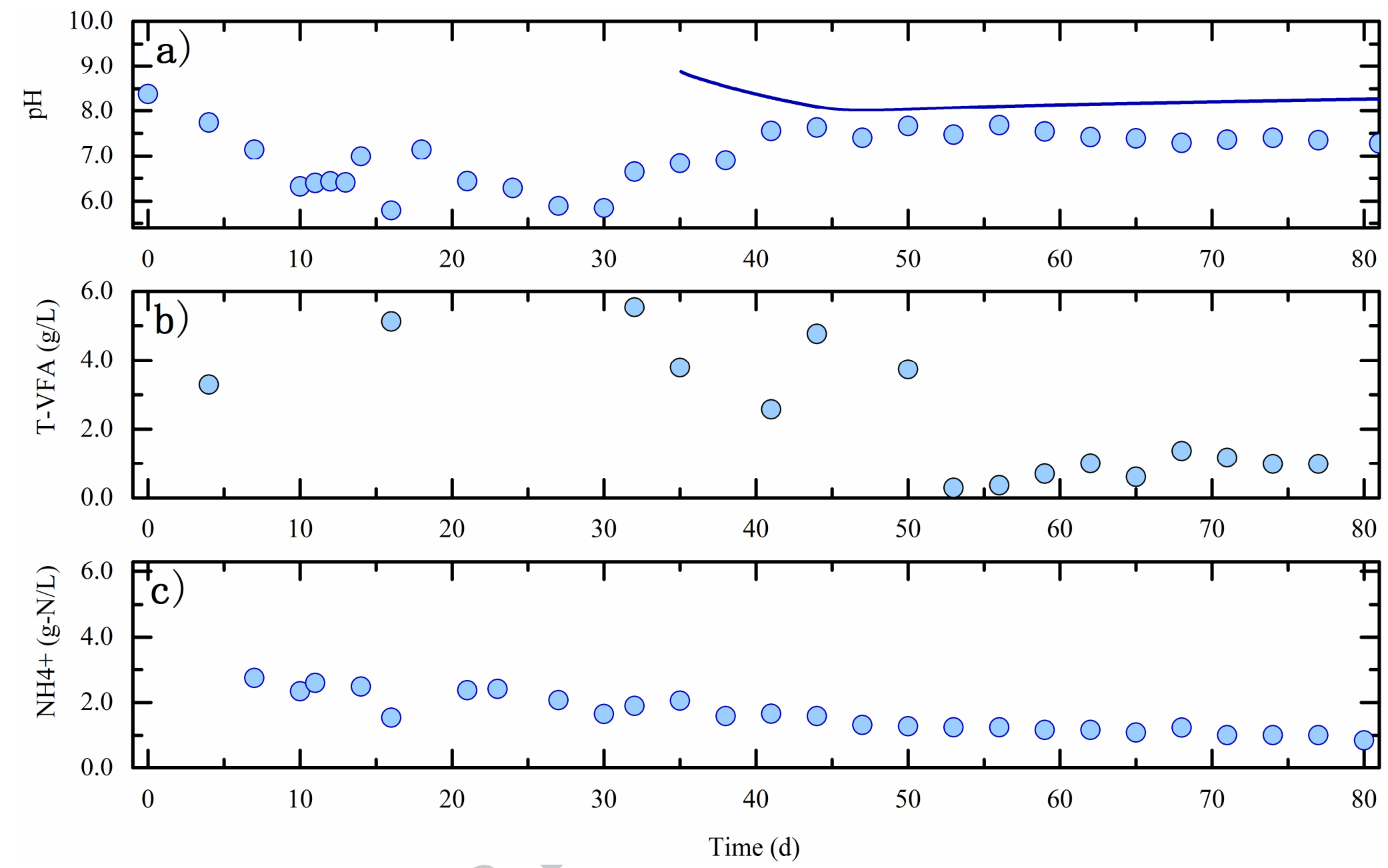

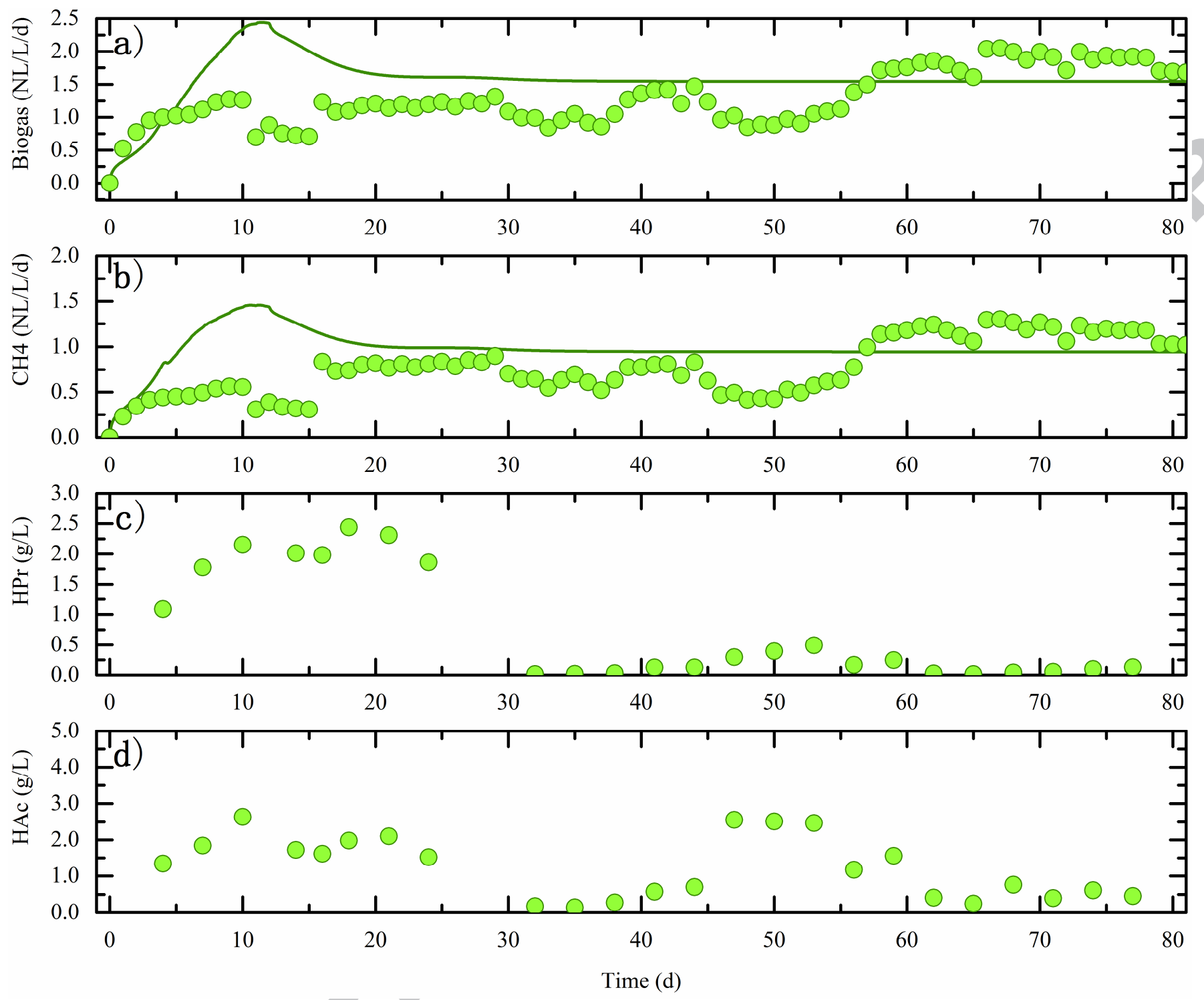
ACCEPTED MANUSCRIPT
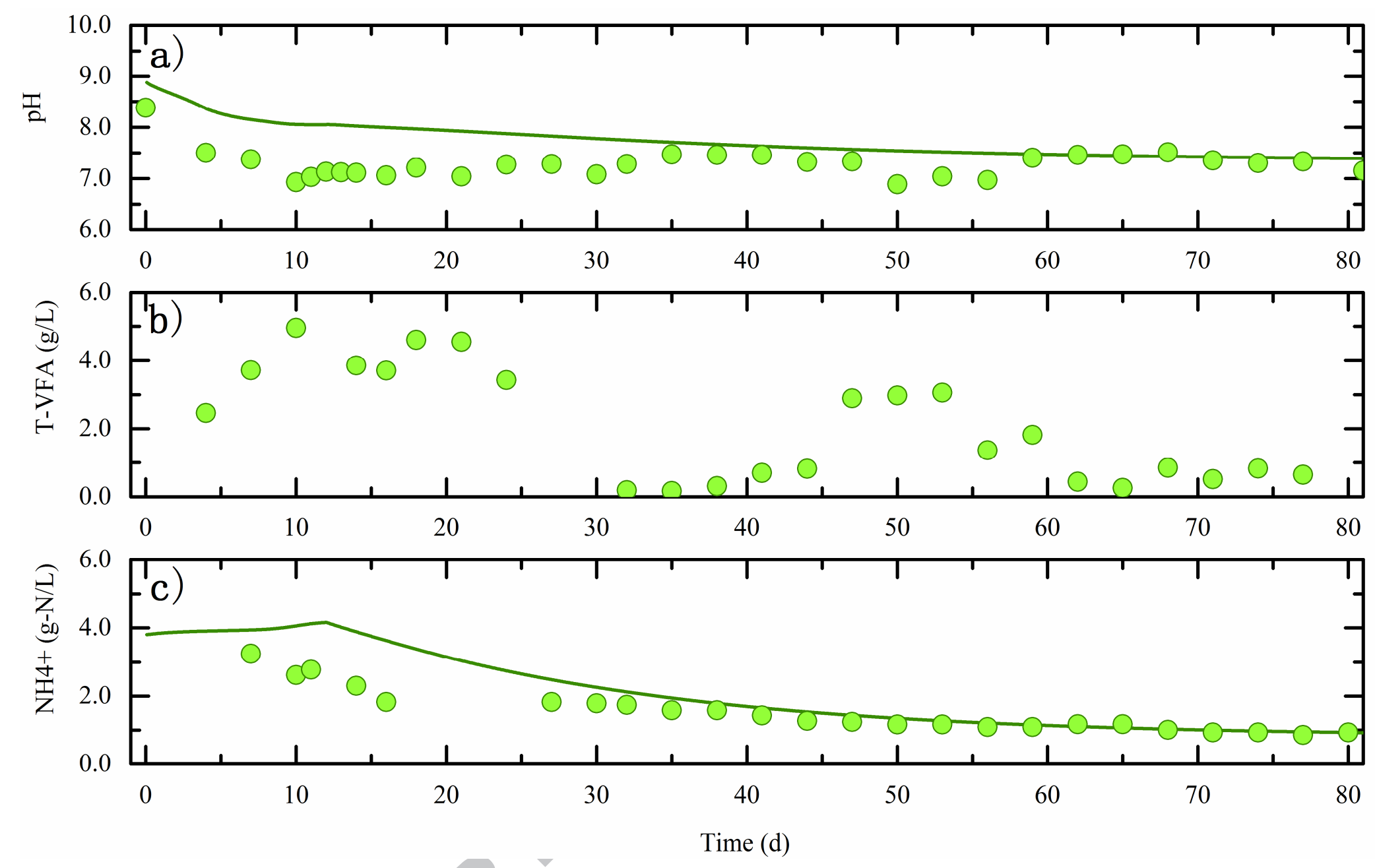

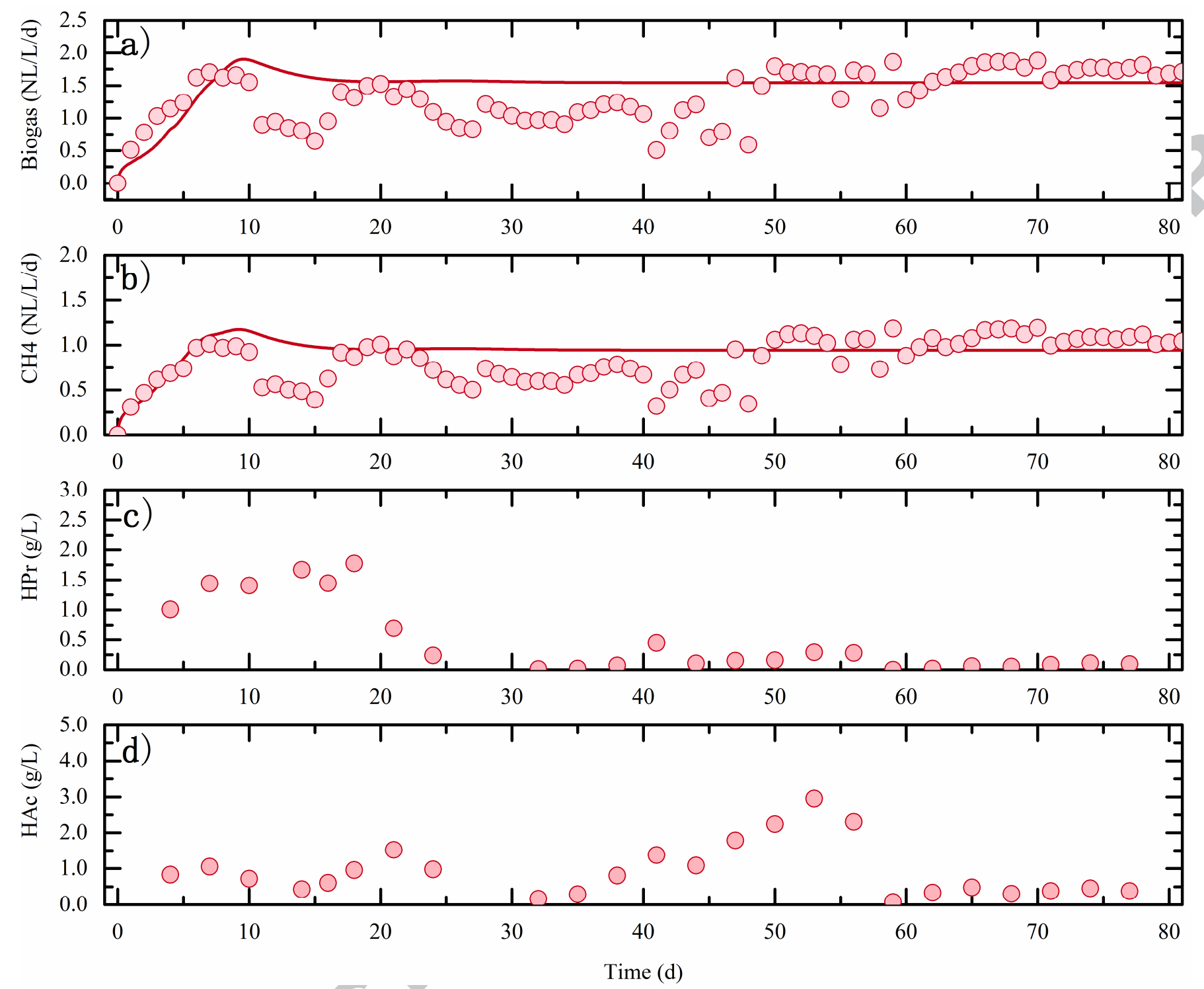
ACCEPTED MANUSCRIPT
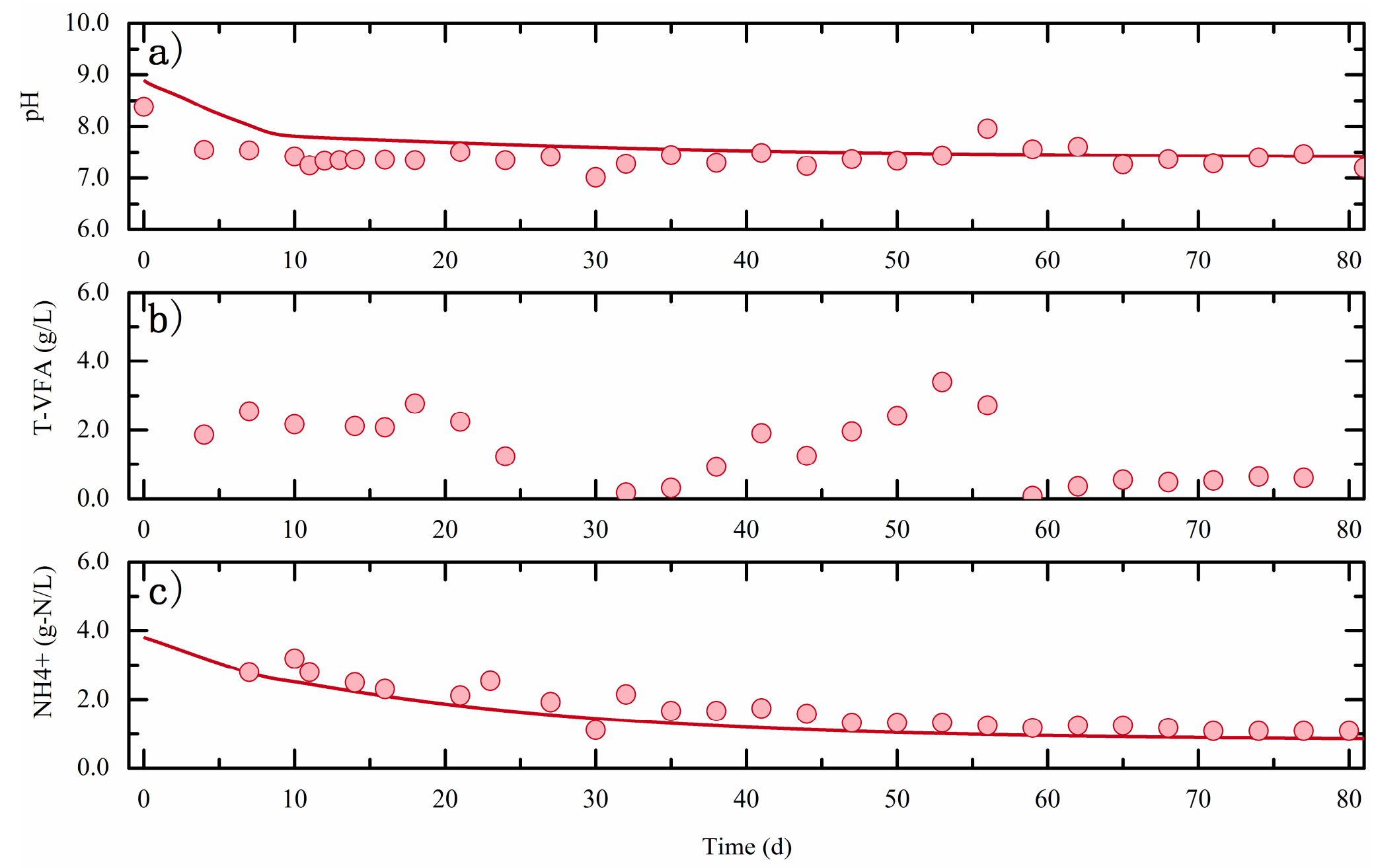


\section{Highlights}

- The anaerobic digestion of source-sorted organic household waste was examined

- High methane yield was produced using batch assays up to $0.49 \mathrm{NLCH}_{4} / \mathrm{gVS}$

- Different start-up strategies of fed-batch reactors were evaluated

- Exponential feeding strategy with 50\% inoculation was the most reliable strategy

- The experimental results were validated using dynamic bioconversion modelling 


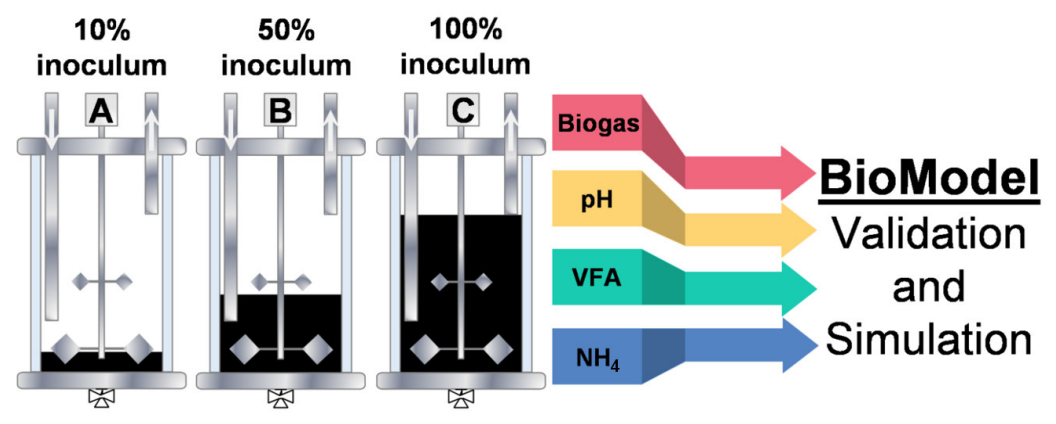

